\title{
大腿骨頸部外側骨折に対するチタン合金製
}

Captured hip screw 法の治療経験

\author{
広島共立病院整形外科 \\ 若 狭 雅彦・岡田 雄 二 \\ 真 鍋 英 喜 \\ 広島鉄道病院整形外科 \\ 立川昌宏 \\ 広島大学医学部整形外科 \\ 村上 恒 二
}

\section{Treatment of Captured Hip Screw Made from Titanium Alloy for the Trochanteric Femoral Fractures}

by

\author{
Masahiko Wakasa, Yuji Okada and Hideki Manabe \\ Department of Orthopedic Surgery, \\ Hiroshima Kyoritsu Hospital \\ Masahiro Tatsugawa \\ Department of Orthopedic Surgery, \\ Hiroshima Tetsudou Hospital \\ Tsuneji Murakami
}

Department of Orthopedic Surgery, Faculty of Medicine,

Hiroshima University

In 77 trochanteric femoral fractures, 40 cases were operated with Ender pinning, 27 cases with Compression hip screw (C. H. S.) and 10 cases with others. In 27 cases with C. H. S., 13 cases were operated with Captured hip screw made from titanium alloy. The average operation time and bleeding volume were 82 minutes, and $164 \mathrm{~g}$ in Ender pinning, and 95 minutes, and $142 \mathrm{~g}$ in C. H. S. respectively. Ten patients ( $25 \%$ ) operated with Ender pinning had complained of gonalgia postoperatirely. Of 13 cases with captured hip screw made from titanium alloy, 6 cases showed shortening of the femoral neck, one varus deformity and one delayed union postoperatirely.

\section{は じめに}

大腿骨頸部外側骨折に対して, 手術時間, 手術侵襲 の点から, Ender 法を勧める報告が多く認められたが, その術後合併症が予想外に多いこと, また，期待する ほど手術侵襲も少くないことから, 現在次第に Compression hip screw (C. H. S.) 法が見直され始めている と言える. 今回われわれは, 従来のステンレス鋼製 C.
H. S. 法に比べて優れていると言われるチタン合金製 C. H.S. 法を使用する機会を得たので, 若干の考察を加え 報告する。

\section{対 象 症 例}

昭和 52 年 11 月, 当院開院以来過去 9 年間で経験し た大腿骨頸部外側骨折は 77 例であり, その術式別分類 では, Ender 法 40 例 (52\%), C. H. S. 法 27 例 (35\%), 
表 1 対象症例

\begin{tabular}{c|c|c}
\hline \hline & Ender 法 & C.H.S. 法 \\
\hline 症例 & 40 例 & 27 例 \\
\hline 性別 & 男:女 $=10: 30$ & 男:女 $=6: 21$ \\
\hline 年令 & 平均81才 (54 92才) & 平均 75 才 (35〜90才) \\
\hline
\end{tabular}

C. H. S. : Compression hip screw

表 2 骨折型分類（Evans）

\begin{tabular}{c|c|c|c}
\hline \hline & Ender 法 & C. H. S. 法 & \\
\hline Stable type & 23 例 & 23 例 & 46 例 \\
\hline Unstable type & 17 例 & 4 例 & 21 例 \\
\hline & 40 例 & 27 例 & 67 例 \\
\hline
\end{tabular}

C. H. S. : Compression hip screw

表 3 結果 (I) 手術侵襲〜 Ender 法との比較〜

\begin{tabular}{c|c|c}
\hline \hline & Ender 法 & C. H.S. 法 \\
\hline 手術 時 間 & 平均 82 分 $(30 \sim 158$ 分 $)$ & 平均 95分 (35〜167分) \\
\hline 術中出血量 & 平均 $164 \mathrm{~g}(13 \sim 394 \mathrm{~g})$ & 平均 $142 \mathrm{~g}(15 \sim 354 \mathrm{~g})$ \\
\hline
\end{tabular}

表 4 結果（II）

1. 手術侵襲について

\begin{tabular}{c|c|c}
\hline \hline & $\begin{array}{c}\text { ステンレス鋼製 } \\
\text { (Howmedica) }\end{array}$ & $\begin{array}{c}\text { チタン合金製 } \\
\text { (Ace) }\end{array}$ \\
\hline (1)手 術 時 間 & 平均120分 (75〜167分) & 平均 69分 (35〜120分) \\
\hline (2)術中出血量 & 平均 $162 \mathrm{~g}(61 \sim 254 \mathrm{~g})$ & 平均 $120 \mathrm{~g}(15 \sim 354 \mathrm{~g})$ \\
\hline
\end{tabular}

2. 後療法について

\begin{tabular}{|c|c|c|}
\hline & $\begin{array}{l}\text { ステンレス鋼製 } \\
\text { (Howmedica) }\end{array}$ & $\begin{array}{c}\text { チタン合金製 } \\
\text { (Ace) }\end{array}$ \\
\hline $\begin{array}{l}\text { (1)起坐開始 } \\
\text { 時期 }\end{array}$ & 平均 9.7日（ $4 \sim 28$ 日） & 平均 3.0 日 ( $1 \sim 7$ 日) \\
\hline $\begin{array}{l}\text { (2)部分荷重 } \\
\text { 開始時期 }\end{array}$ & 平均17.2日 (11～30日) & 平均 9.3日( $3 \sim 20$ 日) \\
\hline $\begin{array}{c}\text { (3)手術より } \\
\text { 退院まで } \\
\text { の期間 }\end{array}$ & 平均 69.0 日 $(31 \sim 110$ 日) & 平均49.4日 (33〜 76日) \\
\hline
\end{tabular}

その他 10 例（13\%）と Ender 法がその過半数を占め ているが, 現在は C. H. S. 法を中心に治療を行ているた
め, Ender 法は隇少傾向にある.なお, C. H. S. 法 27 例 のうちチタン合金製 C. H. S. 法は 13 例である. 性別は, Ender 法が男：女 $=10 ： 30$, CHS 法が $6: 21$ とどちら も女性優位であった。受傷時年例は, それぞれ平均 81 才，75 才であった（表 1)。骨折型は Evans 分類で， Ender 法は stable type 23 例, unstable type 17 例で あり，C. H.S. 法はそれぞれ 23 例， 4 例と Ender 法に unstable type が多かった（表 2 ).

結果

平均手術時間および術中出血量について, Ender 法 と C. H. S. 法を比較すると, Ender 法ではそれぞれ 82 分, $164 \mathrm{~g}$ であるのに対して C. H.S. 法は 95 分, $142 \mathrm{~g}$ であった。骨折型の影響もあると思われるが，予想外 に Ender 法による出血量が多かった。これは最近行っ ているチ夕ン合金製 C. H. S. 法による手術時間, 出血量 が著明に短縮, 減少し, C. H.S. 法全体の平均值を下げ ているためと思われた(表 3 ).さて, C. H. S. 法 27 例 のうち，現在われわれが使用しているチタン合金製 C. H.S. と従来使用していたステンレス鋼製 C. H.S. に関 して, 手術侵襲, 後療法の点について比較検討を行っ た. 手術侵襲に関して, ステンレス鋼製では, 手術時 間平均 120 分, 術中出血量平均 $162 \mathrm{~g}$ であるのに対し て, チタン合金製では，それでれ平均 69 分, $120 \mathrm{~g}$ と 有意に差が認められ, 操作が簡単なため手術時間が短 縮し, 出血量も減少している. 次に, 後療法に関して であるが, ステンレス鋼製では, 起坐開始時期平均 9.7 日, 部分荷重開始時期平均 17.2 日, 手術より退院まで の期間平均 69 日であるのに対して,チタン合金製では 生体適合性, 強度などの点において優れているため, それぞれ平均 3.0，9.3，49.4 日と明らかに後療法が早 くなっている（表 4).

後療法は, stable type で術後数日（ $4 \sim 5$ 日）目から， unstable type で術後 2 週目から部分荷重を開始するこ とを基本原則としている。術後合併症としては, 大腿 骨頸部短縮を 6 例 $(46 \%)$ ， 内反変形, 骨療合遷延 化をそれぞれ 1 例 ( $8 \%$ ) に認めた。頸部短縮は, unstable type $3 / 3$ 例にのみならず stable type $3 / 10$ 例にも認 められた。 そのレ線実測值は, 最小 $2 \mathrm{~mm}$ から最大 14 $\mathrm{mm}$ (平均 $6.5 \mathrm{~mm}$ ) であった.

供

覧

症例 $1: 87$ 才, 男性. 


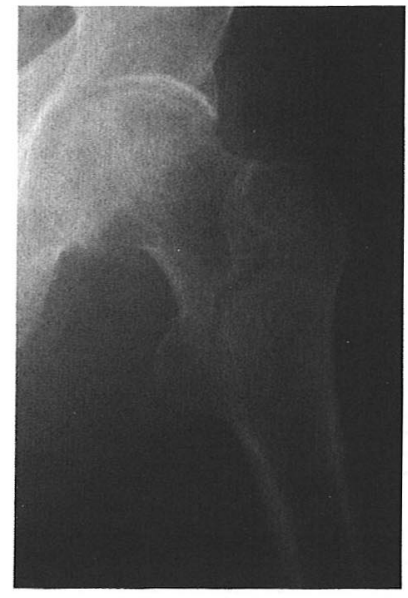

受傷時

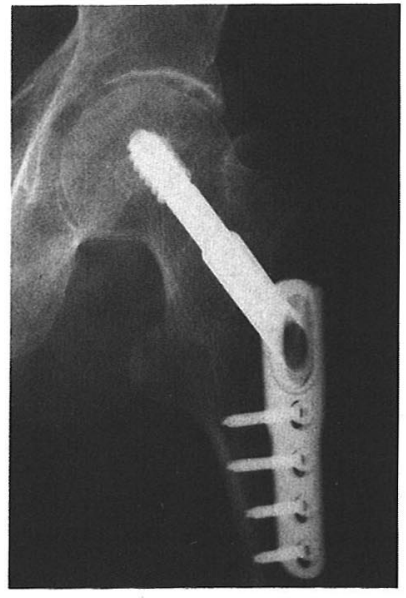

後 1 力月

図 1 症例 1. 安定型

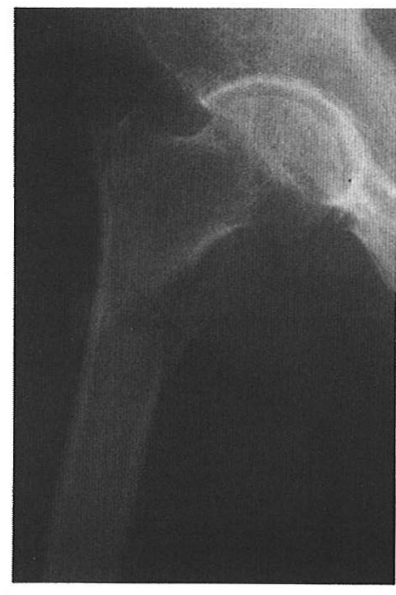

受傷時

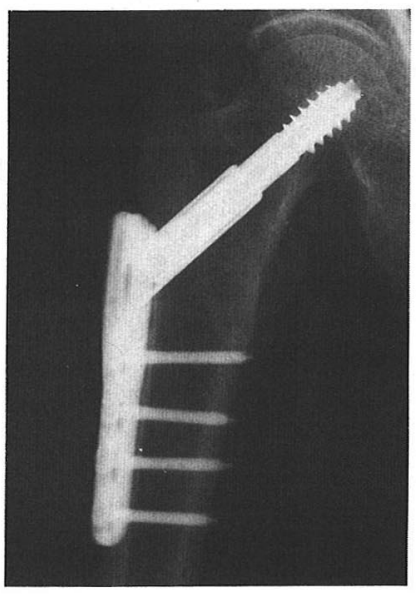

術後 2 週

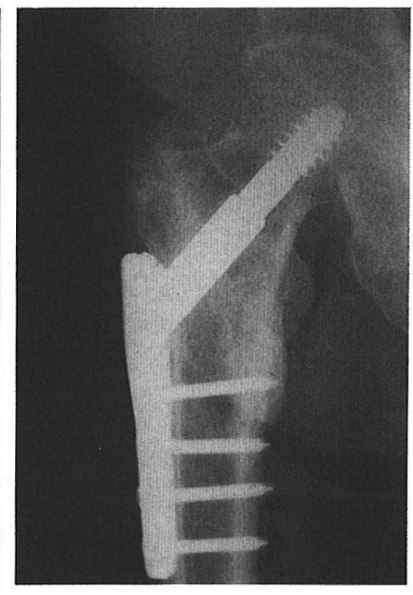

術後 3 力月

図 2 症例 2 . 不安定型

stable type の外側骨折症例である. $135^{\circ}$ captured screw および 4 穴プレートで内固定術施行し, 術中出血 量 $89 \mathrm{~g}$, 手術時間 58 分であった. 術後 2 週で自力歩行 可能となり, 術後 1 力月で退院した（図 1)。

症例 $2: 75$ 才, 女性.

unstable type である。整復位不良であったため, 骨 折部を展開し alignment を整えた後, 同様に内固定術 施行した。術中出血量 $182 \mathrm{~g}$, 手術時間 120 分であった。 unstable type であったため術後 2 週目より部分荷重開 始し, 術後 8 週, 一本杖歩行にて退院した. 術後 3 力
月, 約 $3 \mathrm{~mm}$ の頸部短縮を認めるも骨癒合良好で疼痛 性跛行など認めていない（図 2).

症例 $3: 64$ 才，女性.

unstable type で唯一の成績不良例である。骨頭外反 位で整復され, $145^{\circ}$ の強斜位で内固定術施行した。 unstable type であり, また screw を骨頭外側に刺入し たため, やや遅れて荷重を開始したが, 術後 4 力月頃 より内反変形が出現した。術後 8 力月, 1 本杖歩行可 能であるも,内反変形と共に約 $14 \mathrm{~mm}$ の䫓部短縮を認 める(図 3 ). 


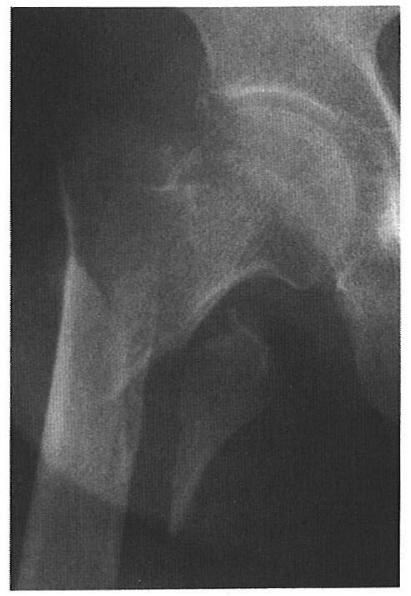

受傷時

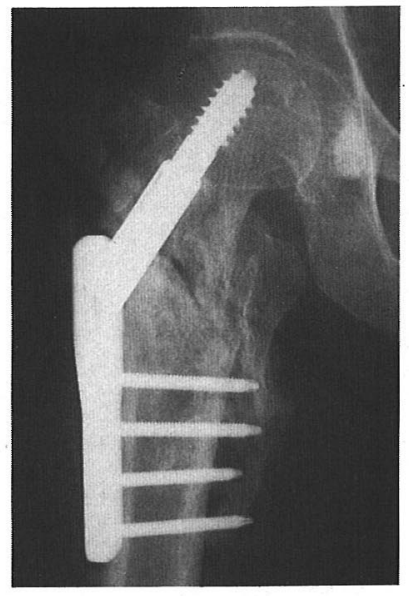

術後 4 力月

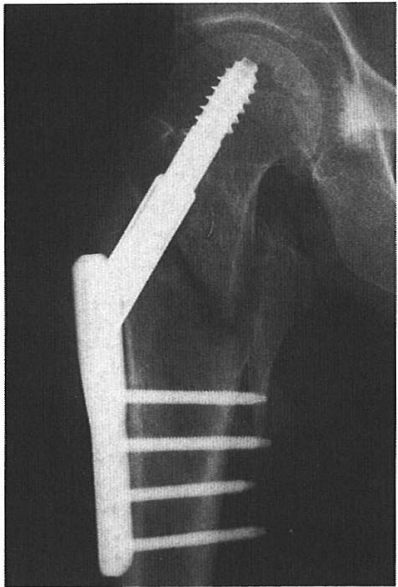

術後 2 週

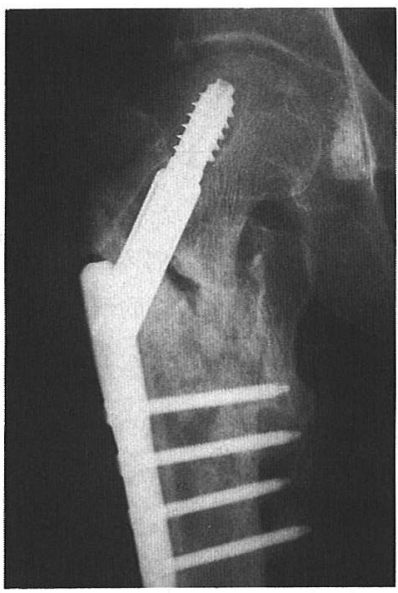

術後 8 力月

図 3 症例 3 . 不安定型

(内反変形)
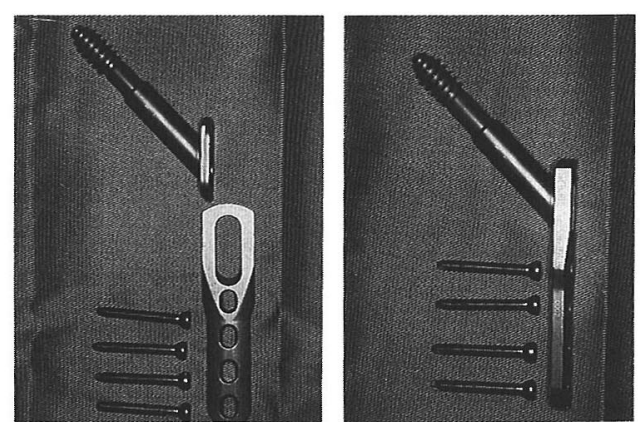

図 4 チタン合金製 Captured hip screw
考

察

高令者の大腿骨頸部骨折の治療は, その術前術後の 合併症の存在から, 強固な内固定を行い, 早期離床さ せることが重要であるといえる。大腿骨頸部外側骨折 に対する主な手術方法"1)は, 1）3 翼釘系－Jewett nail,

2) Blade and plate 系- $\mathrm{AO}$ angle plate, 3) Pinning 系, 4) Sliding naile-plate 系-compression hip screw system 法, 5) Condylo-cephalic nailing 系-Ender 法 のごとく 5 つの体系に分類される。このなかで現在幅 広く支持を得ているのは, Ender 法と C. H. S. 法である. 
われわれも，従来 Ender 法を中心に治療を行ってきた が，1)骨頭内へピンを十分に深く分散して刺入するの に高度な技術を要すること，2）レントゲン被曝線量が 大なること，3）ピンの中枢末梢への逸脱，内反変形， 膝関節の可動制限と疼痛など術後合併症が多く ${ }^{244)}$, こ のため後療法がかえって遅れる傾向にあること，など から現在は,チタン合金製 Captured hip screw 法を中 心にして治療を行っている.従来の C. H. S. 法では, lag screw により plate の方向が決定されるため, 連結操作 時に時として手間取ることがあった ${ }^{3)}$.しかし, 今回わ れわれが使用した captured hip screwは, keyless system のため screw と plate を一体にしたまま挿入で きることから操作が簡略化され，手術時間が短縮し， 出血量も減少した ${ }^{5)}$ (図 4 )。事実今回われわれが調查 した手術侵襲(平均手術時間 69 分, 術中出血量 $120 \mathrm{~g}$ ), 後療法の結果は, Ender 法や従来の C. H. S. 法と比較し ても満足できると考えている.さて, Robert はチタン 合金とステンレス鋼製のスクリューを用いて 4 点曲げ 試験を行い, 物理的性質を比較し，また，Hans は犬を 使った実験において，組織学的測定すなわち軟部組織 との反応性を scoring してチタン合金の有用性を論じて いる5 . その有用性は，1）固定力が強く生理的骨㽷合 を起こさせやすい．2）軟部組織との反応が少い．3） 操作が簡単なため, 手術時間が短縮し, 出血量も減少 する．などがあげられる，以上のことから，骨粗箖症 を伴う高令者において，チタン合金製 Captured hip screw 法は，とくに有用な方法と考えている.

$$
\text { ま と め }
$$

チタン合金製 Captured hip screw 法の有用性につい
て，従来のステンレス鋼製 Compression hip screw 法 や Ender 法と比較検討し報告した。

\section{参 考 文 献}

1）平泉 裕・他：大腿骨頸部骨折に対するチタン合金 製 Captured hip screw の使用経験. 臨整外, 20：1447 $-1450,1985$.

2）井村慎一：大腿骨転子部骨折に対する Ender pin 使 用例の成績と問題点. 整・災外, $26: 157-162,1983$.

3）村田 隆・他：大腿骨頸部外側骨折におけるわれわ れの治療経験 (Ender 法の問題点と dynamic hip screw の治療経験)。整・災外， $27 ： 1683-1687 ， 1984$.

4）根本 元 ・他: Compression hip screw system に よる大腿骨転子部骨折の治療成績. 整・災外, $26: 177$ $-187,1983$

5）大橋俊郎・他：大腿骨頸部外側骨折に対する Compression hip screw system による固定法の治療経験 と基礎的考察. 整形外科, $33: 167-176,1982$.

質問・発言国立福岡東病院 亀山 博生

CHS 法でも, Ender 法でも安定型では成績は良好で あると思います。

不安定型に対し Ender 法では 3 本入れずに 2 本で終 えるなどの幅のある対応ができるが, CHS は one trial なので失敗が許されず困ったことはないか.

\section{解 答広島共立病院 若狭 雅彦}

one trial とは言っても, guide pin を正確に頝部の 中央に刺入しておけば，問題はないと思われる，骨折 部の整復位保持に苦労した事はあるが，drilby の時に 困った経験はない. 